\title{
IMPACT OF SUBSOILING, ORGANIC MANURE AND NITROGEN SOURCES ON SOME SOIL PROPERTIES AND SUGAR BEET PRODUCTIVITY
}

\author{
G. M. A. El-Sanat \\ Soils, Water and Environment Res. Inst., Agric. Res. Center, Egypt.
}

Received: Oct. 9,2017

Accepted: Nov. 9, 2017

\begin{abstract}
A field experiment was conducted at the Experimental Farm of Sakha Agric. Res. Station, during the winter seasons (2014/2015 and 2015/2016) to evaluate the effect of subsoiling and organic manure combined with nitrogen fertilizer sources (ammonia gas and urea) on improving some soil physical and chemical properties as well as sugar beet productivity and $\mathrm{N}$-uptake.
\end{abstract}

The following findings can be summarized as follows: -

The reduction of salinity after two years with subsoiling + urea, subsoiling + ammonia gas and subsoiling + compost + ammonia gas was 2.52, 2.52 and $3.02 \mathrm{dS} / \mathrm{m}$, respectively compared to control. The corresponding values of ESP are 2.20, 2.06 and 2.59, respectively. Compost application was decreased soil salinity and sodicity. Reduction of salinity and sodicity were 0.69 $\mathrm{dS} / \mathrm{m}$ and $0.79 \%$ with compost +urea and $0.63 \mathrm{dS} / \mathrm{m}$ and $0.88 \%$, respectively with compost + ammonia gas compared to control. Nitrogen fertilizer sources (ammonia gas and urea) had no clear effect on salinity and sodicity in the soil.

Subsoiling with and without compost are superior in enhancing soil bulk density and porosity. Average soil bulk density reduced from $1.31 \mathrm{~g} / \mathrm{cm}^{3}$ with control to $1.16 \mathrm{~g} / \mathrm{cm}^{3}$ after treatments application. Basic infiltration rate and cumulative infiltration are increased in the treated soils. The lowest values of basic infiltration rate $(0.59 \mathrm{~cm} / \mathrm{h})$ and cumulative infiltration $(6.28 \mathrm{~cm})$ of soil were achieved under control, while the highest values (from 0.62 to $0.94 \mathrm{~cm} / \mathrm{h}$ for basic infiltration rate and from 7.52 to $12.13 \mathrm{~cm}$ for cumulative infiltration) under other treatments.

Subsoiling are superior to compost in enhancing of quickly drainable pores (QDP), slowly drainable pores (SDP) and fine capillary pores (FCP)) of the soil. The lowest value of QDP (8.17\%) and SDP (9.96\%) and high percent of FCP (28.09\%) are found with control. Treatments application increases QDP (from 9.76 to $13.38 \%$ ) and SDP (10.47 to $15.36 \%$ ) and decreases FCP (24.56 to $17.86 \%)$.

Subsoiling and/or compost as well as nitrogen sources caused significant increases for root yield, juice quality, gross sugar and $\mathrm{N}$-uptake of sugar beet. The increases of sugar beet roots

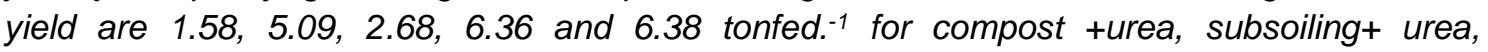
compost+ ammonia gas, subsoiling+ ammonia gas and subsoiling +compost+ ammonia gas, respectively over than control in the first season. The corresponding values were 2.54, 5.26, 3.31, 6.41 and 6.72 tonfed. $^{-1}$, respectively for the abovementioned treatments in the second season. Gross sugar yield and $\mathrm{N}$-uptake were parallel to the yield results in both seasons. The low value of N-uptake by root of sugar beet (average of $36.69 \mathrm{kgfed}^{-1}$ ) was found with control, and the high values (varied from 40.10 to $52.16 \mathrm{kgfed}^{-1}$ ) were found with treatments application in both seasons. Anhydrous ammonia injected gave higher root yield and N-uptake of sugar beet than mineral nitrogen source (urea).

Key words: Subsoiling, clay soil, sugar beet, ammonia injected, compost.

\section{INTRODUCTION}

Subsoiling is widely used on heavy soils

to improve productivity of pastures and crops. Subsoiling in the drainage mode seeks to lift and shatter the soil peds to induce improved structure and so improve 
the water movement to the permanent pipe system (Abdel-Mawgoud et al., 2006 and Antar et al., 2014). Subsoiling will enhance downward movement of irrigation water carrying off excess salts from soil surface layers. After wards, regular subsequent irrigations will gradually reduce the salt content in groundwater at least when close to soil surface. The percolating water will constitute a temporary front preventing the saline groundwater in subsurface soil layers from linking with the upper ones (Moukhtar et al., 2002 and 2003).

Improved crop growth following subsoiling is generally considered to be the result of the physical shattering of the hardpan, which allows to increase water penetration into the subsoil. This may also accelerate the leaching of sodium from the subsoil thereby further reducing the possibility of reformation of the hardpan (Lickacz, 1993). Said (2002) revealed that soil compaction influenced soil strength, bulk density, distribution and continuity of pores with consequent an adverse effect on drainage, root penetration, aeration, biological processes and nutrient uptake; all of which could have a direct bearing on crop production. The cumulative and basic infiltration rate of the treated soil by subsoiling markedly increased relative to the untreated one. He also, found that the treated soil resulted in a sharp decrease in the bulk density and penetration resistance in coincidence with a sharp increase in total porosity and macro pores relative to the untreated one (Said, 2003).

To decide the amount of fertilizers to apply, the farmer usually considers the crop requirement and sometimes the nitrogen stored in the soil at beginning of the crop cycle, but there is no evaluation of the soil capability to provide nitrogen minerals from its organic pool. Anhydrous ammonia is one of the most efficient and widely used as source of nitrogen for plant growth. The advantages of ammonia relatively easy application and ready availability have led to its increased use as a fertilizer. The anhydrous ammonia when injected before sowing, gave higher yield and minerals uptake than other nitrogen sources (Abd ElKader, 2002). Ammonia gas progressed than urea for sugar beet root yield and gave maximum root yield (30.8 ton / fed.) (Atia et al., 2007). Ammonia gas is good and cheaper source of nitrogen fertilizer compared with any other $\mathrm{N}$ source and gave the maximum economic return from sugar beet cultivation (Zalat et al. 2011). Injected ammonia gas at level (102 kg fed-1.) gave the highest root, sugar and top yields compared with other levels under study (0, 45 and $75 \mathrm{~kg} \mathrm{fed}^{-1}$ ) as well as N, P, K and $\mathrm{Na}$ content than urea fertilizer (Mostafa and Darwish, 2001). On the other hand, increasing levels of ammonia gas injection decrease sucrose and purity percentage.

Soil degradation and nutrient have become serious threat to agricultural productivity, especially in clayey soil. Nowadays, it is recognizing the importance of improving soil fertility to ensure efficient crop production. Applying organic manure and gypsum to a clayey soil are an important practice in sustaining soil fertility and agricultural productivity. In this connection, the application of farmyard manure (FYM) showed significant increases in available $P$ and $K$ contents of the soil (Yadav and Chhipa, 2007). The interaction between application of compost, Sulphur and NP fertilizer gave the lowest values of bulk density and the highest values of total porosity and basic infiltration rate (El-Hamdi et al. 2007). The addition of organic matter to soils improved the structural stability and permeability (Bouajila and Sanaa, 2011). Injected ammonia gas was the best one in $1^{\text {st }}$ and $2^{\text {nd }}$ seasons followed by farm manure + urea treatment in root yield and its $\mathrm{N}$ uptake (Antar and Awad, 2014).

Sugar beet (Beta vulgaris L) is the second important crop for sugar production in Egypt. The importance of this crop comes not only for its ability for growing in the new 
reclaimed lands, but also for giving higher sugar content and short growth period. Also, sugar beet is widely grown in areas with salinity problems. So, there is a great need for several studies under Egyptian soil conditions to establish the best recommendations for raising the quantity and quality of sugar beet production. One way of increasing production of sugar beet is proper soil management such as drainage and increasing the efficiency of added nitrogen fertilizer. The current study aims to evaluate the effect of subsoiling and organic manure combined with nitrogen fertilizer sources (ammonia gas and urea) on improving some soil physical and chemical properties as well as sugar beet productivity and N-uptake.

\section{MATERIALS AND METHODS}

A field experiment was conducted at the Experimental Farm of Sakha Agric. Res. Station, during the winter seasons (2014/2015 and 2015/2016) to evaluate the effect of some amendments application and nitrogen fertilizer sources on improving some soil physio-chemical properties and sugar beet productivity. The experiment is located at $31^{\circ} 05^{\circ} 13.8^{\prime \prime}$ Latitude and $30^{\circ} 56$ $10.6^{\longleftarrow}$ Longitude. The soil has a clayey texture; the average textural for this soil is $11.8 \%$ sand, $33.5 \%$ silt and $54.7 \%$ clay (Table 1). Initial of some soil properties are presented in Table (1).
The design of the experiment is randomized complete block and was established before winter season (2014/2015) as follows:

1: Urea (control) (as the farmer).

2: Urea+ compost.

3: Urea + subsoiling.

4: Ammonia gas +compost.

5: Ammonia gas + subsoiling.

6- Subsoiling with compost + ammonia gas.

"Urea and ammonia gas were applied at a rate of $120 \mathrm{~kg} \mathrm{~N}$ fed.-1(as recommended), compost was added at rate of $12 \mathrm{~m}^{3} / \mathrm{fed}$ and subsoiling was established at $1.5 \mathrm{~m}$ distance between the ploughed lines and $50 \mathrm{~cm}$ depth."

The salinity of irrigation water ranges between $0.5-0.6 \mathrm{dSm}^{-1}$ with an average of $0.55 \mathrm{dSm}^{-1}$.

In the winter seasons (2014/2015 and 2015/2016) sugar beet (pleno variety) was planted. All plots received $100 \mathrm{~kg} / \mathrm{fed}$. of superphosphate $\left(15.5 \% \quad \mathrm{P}_{2} \mathrm{O}_{5}\right)$ before cultivation. Nitrogen (as urea) was applied in three doses before the first, second and the third irrigations. Nitrogen (as ammonia gas) was injected at 10 to $15 \mathrm{~cm}$ soil depth, before cultivation. After five days from ammonia gas injection, seeds were sown and planting irrigation was applied. The different agricultural practices were done as recommended.

Table (1): The initial of some soil properties for the experimental field

\begin{tabular}{|c|c|c|c|c|c|c|c|c|c|c|c|c|}
\hline \multirow{2}{*}{$\begin{array}{l}\text { Soil } \\
\text { depth } \\
\text { (cm) }\end{array}$} & \multicolumn{3}{|c|}{$\begin{array}{l}\text { Particle size } \\
\text { distribution }\end{array}$} & \multirow{2}{*}{$\begin{array}{l}\text { Texture } \\
\text { grade }\end{array}$} & \multirow{2}{*}{$\begin{array}{c}\mathrm{EC} \\
(\mathrm{dS} / \mathrm{m})\end{array}$} & \multirow{2}{*}{ ESP } & \multirow{2}{*}{$\begin{array}{c}\text { CEC } \\
\text { Meq/100 } \\
\text { soil }\end{array}$} & \multirow{2}{*}{$\mathrm{pH}$} & \multirow{2}{*}{$\begin{array}{l}\text { OM } \\
\%\end{array}$} & \multirow{2}{*}{$\mid \begin{array}{c}\text { Available } \\
\mathrm{N} \\
(\mathrm{mg} / \mathrm{kg})\end{array}$} & \multirow{2}{*}{$\begin{array}{c}\text { Bulk } \\
\text { density } \\
\text { g/cm }\end{array}$} & \multirow{2}{*}{$\begin{array}{c}\mathrm{IR} \\
(\mathrm{cm} / \mathrm{h})\end{array}$} \\
\hline & Sand\% & Silt\% & Clay\% & & & & & & & & & \\
\hline $0-15$ & 13.67 & 32.55 & 53.78 & Clayey & 6.58 & 15.17 & 42.63 & 8.17 & 1.98 & 24 & 1.24 & \multirow{4}{*}{0.59} \\
\hline $15-30$ & 13.68 & 32.09 & 54.23 & Clayey & 7.97 & 15.82 & 39.72 & 8.12 & 0.97 & 18 & 1.29 & \\
\hline $30-60$ & 13.88 & 32.63 & 53.49 & Clayey & 8.77 & 16.67 & 38.05 & 8.15 & 0.58 & 12 & 1.38 & \\
\hline Mean & 13.74 & 32.42 & 53.83 & Clayey & 7.77 & 15.89 & 40.13 & 18.15 & 1.18 & 18 & 1.30 & \\
\hline
\end{tabular}


Soil samples $(0-15,15-30$ and $30-60 \mathrm{~cm}$ depth) were collected before conducting the experiment and after harvesting the first and second seasons from treatments for some physical and chemical analysis. Salinity was determined in saturated soil paste extract according to Page et al. (1982). Exchangeable sodium was determined using ammonium chloride and measured by using flame photometer according to Page et al. (1982). Infiltration rate was determined using double cylinder infiltrometer as described by Garcia (1978). Soil bulk density and total porosity of the different layers of soil profile were measured after first and second seasons using the core sampling technique as described by Campbell (1994) for all treatments. Pore size distribution was calculated from soil moisture retention curves according to DeLeenher and De Boodt (1965). Soil pores are classified according to their size and ability to retain water at different pressure head, to quickly drainable pores (QDP) that can hold water between 0.00 and $100 \mathrm{~cm}$ head, slowly drainable pores (SDP) difference between 100 and $330 \mathrm{~cm}$ head. Water holding pores (WHP) or medium pores which retain soil moisture between field capacity $(330 \mathrm{~cm}$ head) and wilting point $(15000 \mathrm{~cm}$ head) and fine capillary pores (FCP) which retained soil moisture at suction head of $15.0 \mathrm{~atm}$.

Root and shoot, ton fed ${ }^{-1}$ of sugar beet were determined for different treatments while sucrose concentration and juice purity (\%) for all treatments were determined in Delta Sugar Company at El-Hamoul, Kafr ElSheikh Governorate. Gross sugar yield (ton/fed) was calculated by multiplying root yield (ton/fed) by sucrose and juice purity (\%). Root and shoot samples for beet were taken and dried at $70^{\circ} \mathrm{C}$, grounded with a mill and its total $\mathrm{N}$ content was determined using Kjeldahl digestion (Cottenie et al., 1982). N-uptake (kg/fed.) was calculated by multiplying dry yield $(\mathrm{kg} / \mathrm{fed}$.) by $\mathrm{N} \%(\mathrm{~N}$ content in percentage either for root and shoot). Available $\mathrm{N}$ content of soil was determined using Kjeldahl digestion (Cottenie et al., 1982).

Statistical analysis: Data for yield and yield component of sugar beet plant are subjected to statistical analysis according to Snedecor and Cochran (1980).

\section{RESULTS AND DISCUSSION Soil salinity and sodicity:}

Data in Table (2) show that, treatments application seems to be favorable effective in decreasing of soil salinity and sodicity. Subsoiling application are more pronounced on reduction of salinity and sodicity compared to other treatments. Salinity and sodicity of the soil increased with the increasing of soil depth. Salinity and sodicity of the soil, under urea (control) are relatively high ( $E C_{e}$ varied from 6.52 to $8.97 \mathrm{dS} / \mathrm{m}$ and ESP from 15.22 to 16.77 ) comparing with other treatments (varied from 3.87 to 8.36 $\mathrm{dS} / \mathrm{m}$ for $\mathrm{EC}_{\mathrm{e}}$ and 12.26 to 16.27 for ESP). The decreases of soil salinity and sodicity after two years of treatments application are more pronounced compared to after one year (Table, 2). The reduction of salinity, after two years with compost+urea, subsoiling + urea, compost + ammonia gas, subsoiling + ammonia gas and subsoiling + compost + ammonia gas were $0.69,2.52$, $0.63,2.52$ and $3.02 \mathrm{dS} / \mathrm{m}$, respectively than urea (control). The corresponding values of ESP are 0.79, 2.20, 0.88, 2.06 and 2.59, for the stated treatments, respectively.

The effect of the treated treatments on improving soil desalinization, desodification are shown in Table (2). It should be mentioned that the greatest desalinization occurs after subsurface tillage. Results could be attributed mainly to that subsoil forms many lines with big crack extend from soil surface to subsoil depth and also numerous effective capillary cracks is formed. All these cracks together break the soil matrix and encourage downward of 
water as well as solute movement. The soil cracks life may be several months or years (Moukhtar et al., 2002). Moukhtar et al, (2003) reported that, subsoiling enhance downward movement of irrigation water carrying off excess salts from surface layers. After wards, regular subsequent irrigations will gradually reduce the salt content in groundwater at least when it is close to soil surface.
Compost application (Table, 2) were realized somewhat in lower soil salinity and sodicity than the control. This may be due to the improved soil physical properties such as bulk density, porosity, aggregates stability and infiltration rate that affect waterair relationships in the root zone (Doran and Parking, 1994). Nitrogen fertilizer sources (ammonia gas and urea) had no clear effect on salinity and sodicity in the soil.

Table (2): Salinity and sodicity of the soil as affected by the different studied treatments.

\begin{tabular}{|c|c|c|c|c|c|}
\hline \multirow{2}{*}{ Treatments } & \multirow{2}{*}{$\begin{array}{l}\text { Soil depth } \\
\quad(\mathrm{cm})\end{array}$} & \multicolumn{2}{|c|}{ After first season } & \multicolumn{2}{|c|}{ After second season } \\
\hline & & $\mathrm{EC} \mathrm{dSm}{ }^{-1}$ & ESP & $\mathrm{EC} \mathrm{dSm} \mathrm{d}^{-1}$ & ESP \\
\hline \multirow{3}{*}{ Urea (control). } & $0-15$ & 6.52 & 15.27 & 6.59 & 15.22 \\
\hline & $15-30$ & 7.93 & 15.82 & 7.84 & 15.86 \\
\hline & $30-60$ & 8.97 & 16.67 & 8.69 & 16.77 \\
\hline \multicolumn{2}{|l|}{ Average } & 7.81 & 15.92 & 7.71 & 15.95 \\
\hline \multirow{3}{*}{ Urea + compost. } & $0-15$ & 6.08 & 14.84 & 5.89 & 14.15 \\
\hline & $15-30$ & 7.23 & 15.54 & 7.12 & 15.22 \\
\hline & $30-60$ & 8.36 & 16.27 & 8.06 & 16.11 \\
\hline \multicolumn{2}{|l|}{ Average } & 7.22 & 15.55 & 7.02 & 15.16 \\
\hline \multirow{3}{*}{ Urea + subsoiling. } & $0-15$ & 5.45 & 13.74 & 4.84 & 13.25 \\
\hline & $15-30$ & 5.42 & 14.52 & 4.88 & 13.64 \\
\hline & $30-60$ & 6.35 & 14.68 & 5.86 & 14.35 \\
\hline \multicolumn{2}{|l|}{ Average } & 5.74 & 14.31 & 5.19 & 13.75 \\
\hline \multirow{3}{*}{ Ammonia gas + compost } & $0-15$ & 6.84 & 14.68 & 6.12 & 14.35 \\
\hline & $15-30$ & 6.87 & 15.29 & 7.24 & 14.89 \\
\hline & $30-60$ & 7.99 & 16.11 & 7.89 & 15.97 \\
\hline \multicolumn{2}{|l|}{ Average } & 7.23 & 15.36 & 7.08 & 15.07 \\
\hline \multirow{3}{*}{ Ammonia gas+subsoiling } & $0-15$ & 4.84 & 13.24 & 4.31 & 12.88 \\
\hline & $15-30$ & 5.64 & 14.53 & 5.14 & 13.54 \\
\hline & $30-60$ & 6.74 & 15.41 & 6.11 & 15.26 \\
\hline \multicolumn{2}{|l|}{ Average } & 5.74 & 14.39 & 5.19 & 13.89 \\
\hline \multirow{3}{*}{$\begin{array}{l}\text { Ammonia gas }+ \\
\text { subsoiling }+ \text { compost }\end{array}$} & $0-15$ & 4.22 & 13.11 & 3.87 & 12.26 \\
\hline & $15-30$ & 5.11 & 14.12 & 4.52 & 13.17 \\
\hline & $30-60$ & 6.01 & 15.03 & 5.68 & 14.66 \\
\hline \multicolumn{2}{|l|}{ Average } & 5.11 & 14.09 & 4.69 & 13.36 \\
\hline
\end{tabular}




\section{Soil bulk density and Soil porosity}

Soil bulk density is considered as one of the parameters which indicate the status of soil structure and consequently soil water, air and heat regimes (Richards, 1954). Results in Table (3) show that, soil bulk density is increased with increasing soil depth for all tested profiles. This increase may be resulted from increasing soil compaction due to layers weight. Treatments application reduced soil bulk density, especially in the top-layer $(0-30 \mathrm{~cm})$. Values of soil bulk density under control are relatively high (varied from 1.27 to 1.38 $\mathrm{g} / \mathrm{cm}^{3}$ ) at the first season comparing with other treatments (varied from 1.07 to 1.31 $\mathrm{g} / \mathrm{cm}^{3}$ ). Subsoiling with and without compost were superior to other treatments on reducing soil bulk density. It could be attributed to the effects of subsoiling on breaking soil clods and bigger granular into smaller crumbs as well as breaking and cracking the compacted layers (Amer, 1999 and Abdel-Mawgoud et al., 2006). The applied compost were realized favorable effects in soil bulk density especially in the top soil layer $(0-20 \mathrm{~cm})$. Similar results were obtained by Aiad et al., (2012). In this concern, Cook et al., (1979) reported that, improvement of the soil after compost application included an increase in water infiltration rate, a decrease in bulk density, and an increase in pore volume. The effect of subsoiling and/or compost treatments after two seasons were more pronounced relative to after one season in decreasing the soil bulk density.

Soil porosity values (Table 3 ) take almost the opposite trend to that encountered with bulk density. The results indicate that the values of bulk density were increased and values of total porosity were decreased with the depth for all treatments. Subsoiling with and without compost are superior in enhancing soil porosity. Jodi DeJong (2004) stated that the theory behind subsoiling is to shatter a deep compacted layer in the soil to increase water movement, increase total porosity, create better aeration for the root and increase the availability of nutrients for plant growth. Bulk density and total porosity of the soil do not affect by nitrogen fertilizer sources (ammonia gas and urea).

\section{Infiltration rate (IR) and cumulative infiltration:}

Data illustrated in Table (4) and Figs $(1,2,3$ and 4$)$ show that, basic infiltration rate and cumulative infiltration values after each season are increased in the treated soils. The lowest values of basic infiltration rate $(0.58 \mathrm{~cm} / \mathrm{h})$ and cumulative infiltration $(6.28$ $\mathrm{cm}$ ) of soil was achieved under control treatment, while the highest values (varied from 0.62 to $0.94 \mathrm{~cm} / \mathrm{h}$ for basic and 7.52 to $12.13 \mathrm{~cm}$ for cumulative infiltration) under other treatments at the first season. Subsoiling with and without compost were superior to compost without subsoiling on enhancing of infiltration rate and cumulative infiltration. This due to the tillage by subsoiling gave the top soil layer a chance to dry and permitted for shrinkage and formation of water passage ways which allowed a rather easier movement of water into subsoil line. Similar results were obtained by Abdel-Mawgoud et al., (2004 and 2006). Also, application of treated compost realized favorable effects for infiltration rate and cumulative infiltration. Basic and cumulative infiltration values were higher with compost treatments than the control especially, after the second season. Similar results were obtained by Aiad et al., (2012). Infiltration rate and cumulative infiltration do not affect by nitrogen fertilizer sources (ammonia gas and urea). 
Table (3): Soil bulk density and total porosity after the first and second seasons as affected by treatments application.

\begin{tabular}{|c|c|c|c|c|c|}
\hline \multirow[b]{2}{*}{ Treatments } & \multirow{2}{*}{$\begin{array}{l}\text { Depth } \\
(\mathrm{cm})\end{array}$} & \multicolumn{2}{|c|}{ After first season } & \multicolumn{2}{|c|}{ After second season } \\
\hline & & $\begin{array}{c}\text { Soil bulk } \\
\text { density } \mathrm{g} / \mathrm{cm}^{3}\end{array}$ & $\begin{array}{c}\text { Porosity } \\
\%\end{array}$ & $\begin{array}{c}\text { Soil bulk } \\
\text { density } \mathrm{g} / \mathrm{cm}^{3}\end{array}$ & $\begin{array}{c}\text { Porosity } \\
\%\end{array}$ \\
\hline \multirow{3}{*}{ Urea (control). } & $0-15$ & 1.27 & 52.08 & 1.28 & 51.70 \\
\hline & $15-30$ & 1.29 & 51.32 & 1.27 & 52.08 \\
\hline & $30-60$ & 1.38 & 47.92 & 1.36 & 48.68 \\
\hline \multicolumn{2}{|l|}{ Average } & 1.31 & 50.44 & 1.30 & 50.82 \\
\hline \multirow{3}{*}{ Urea + compost. } & $0-15$ & 1.21 & 54.34 & 1.17 & 55.85 \\
\hline & $15-30$ & 1.25 & 52.83 & 1.24 & 53.21 \\
\hline & $30-60$ & 1.31 & 50.57 & 1.30 & 50.94 \\
\hline \multicolumn{2}{|l|}{ Average } & 1.26 & 52.58 & 1.24 & 53.33 \\
\hline \multirow{3}{*}{ Urea +subsoiling. } & $0-15$ & 1.13 & 57.36 & 1.11 & 58.11 \\
\hline & $15-30$ & 1.20 & 54.72 & 1.19 & 55.09 \\
\hline & $30-60$ & 1.29 & 51.32 & 1.28 & 51.70 \\
\hline \multicolumn{2}{|l|}{ Average } & 1.21 & 54.47 & 1.19 & 54.97 \\
\hline \multirow{3}{*}{$\begin{array}{l}\text { Ammonia gas + } \\
\text { compost. }\end{array}$} & $0-15$ & 1.19 & 55.09 & 1.15 & 56.60 \\
\hline & $15-30$ & 1.27 & 52.08 & 1.27 & 52.08 \\
\hline & $30-60$ & 1.31 & 50.57 & 1.30 & 50.94 \\
\hline \multicolumn{2}{|l|}{ Average } & 1.26 & 52.58 & 1.24 & 53.21 \\
\hline \multirow{3}{*}{$\begin{array}{l}\text { Ammonia gas } \\
\text { +subsoiling }\end{array}$} & $0-15$ & 1.10 & 58.49 & 1.11 & 58.11 \\
\hline & $15-30$ & 1.24 & 53.21 & 1.19 & 55.09 \\
\hline & $30-60$ & 1.24 & 53.21 & 1.27 & 52.08 \\
\hline \multicolumn{2}{|l|}{ Average } & 1.19 & 54.97 & 1.19 & 55.09 \\
\hline \multirow{3}{*}{$\begin{array}{l}\text { Ammonia gas + } \\
\text { subsoiling }+ \\
\text { compost }\end{array}$} & 0-15 & 1.08 & 59.25 & 1.07 & 59.62 \\
\hline & $15-30$ & 1.17 & 55.85 & 1.15 & 56.60 \\
\hline & $30-60$ & 1.22 & 53.96 & 1.22 & 53.96 \\
\hline \multicolumn{2}{|l|}{ Average } & 1.16 & 56.35 & 1.15 & 56.73 \\
\hline
\end{tabular}

Table (4): Basic infiltration rate $(\mathrm{cm} / \mathrm{h})$ and cumulative infiltration $(\mathrm{cm})$ after the first and second seasons as affected by treatments application.

\begin{tabular}{|l|c|c|c|c|}
\hline \multirow{2}{*}{ Treatments } & \multicolumn{2}{|c|}{ First season } & \multicolumn{2}{c|}{ Second season } \\
\cline { 2 - 5 } & $\begin{array}{c}\text { Basic IR } \\
(\mathrm{cm} / \mathrm{h})\end{array}$ & $\begin{array}{c}\text { Cumulative } \\
\text { infiltration }(\mathrm{cm})\end{array}$ & $\begin{array}{c}\text { Basic IR } \\
(\mathrm{cm} / \mathrm{h})\end{array}$ & $\begin{array}{c}\text { Cumulative } \\
\text { infiltration }(\mathrm{cm})\end{array}$ \\
\hline Urea (control) & 0.58 & 6.28 & 0.59 & 6.59 \\
\hline Urea + compost & 0.62 & 7.52 & 0.69 & 8.19 \\
\hline Urea + subsoiling & 0.94 & 11.54 & 0.92 & 11.42 \\
\hline Ammonia gas + compost. & 0.63 & 7.93 & 0.68 & 8.68 \\
\hline Ammonia gas + subsoiling & 0.93 & 11.48 & 0.93 & 11.93 \\
\hline Ammonia gas + subsoiling+ compost & 0.94 & 12.13 & 0.93 & 12.11 \\
\hline
\end{tabular}




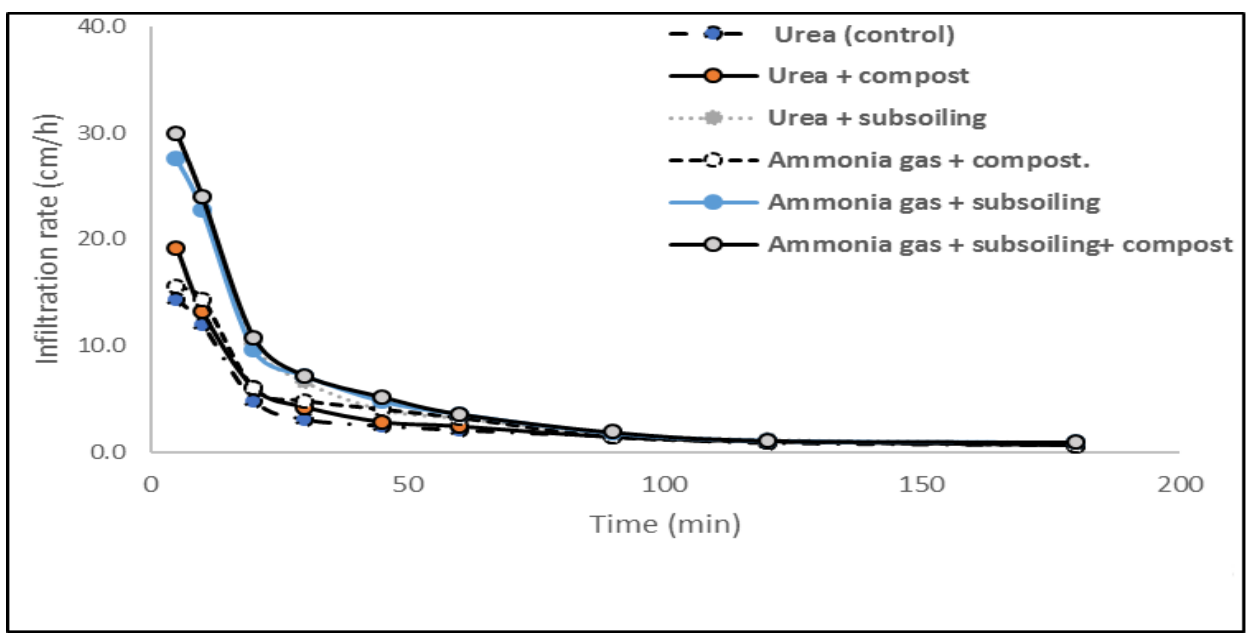

Fig. (1): Infiltration rate $(\mathrm{cm} / \mathrm{h})$ after the first season as affected by treatments application.

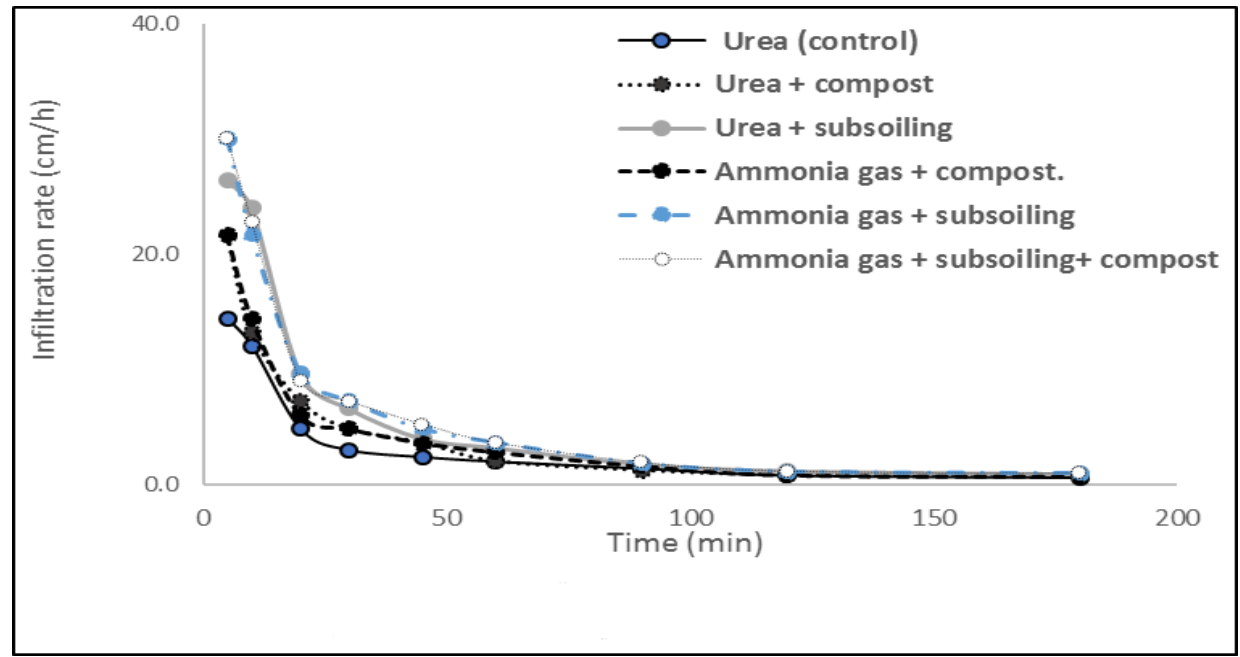

Fig. (2): Infiltration rate $(\mathrm{cm} / \mathrm{h})$ after the second season as affected by treatments application.

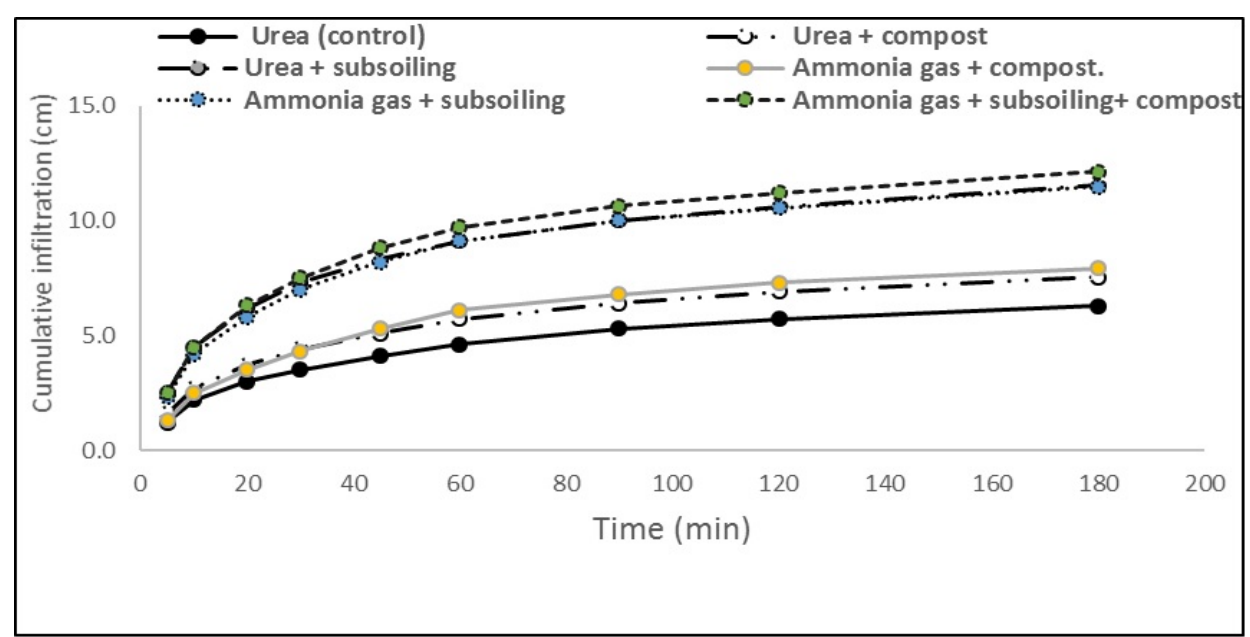

Fig. (3): Cumulative infiltration (cm) after the first season as affected by treatments application. 


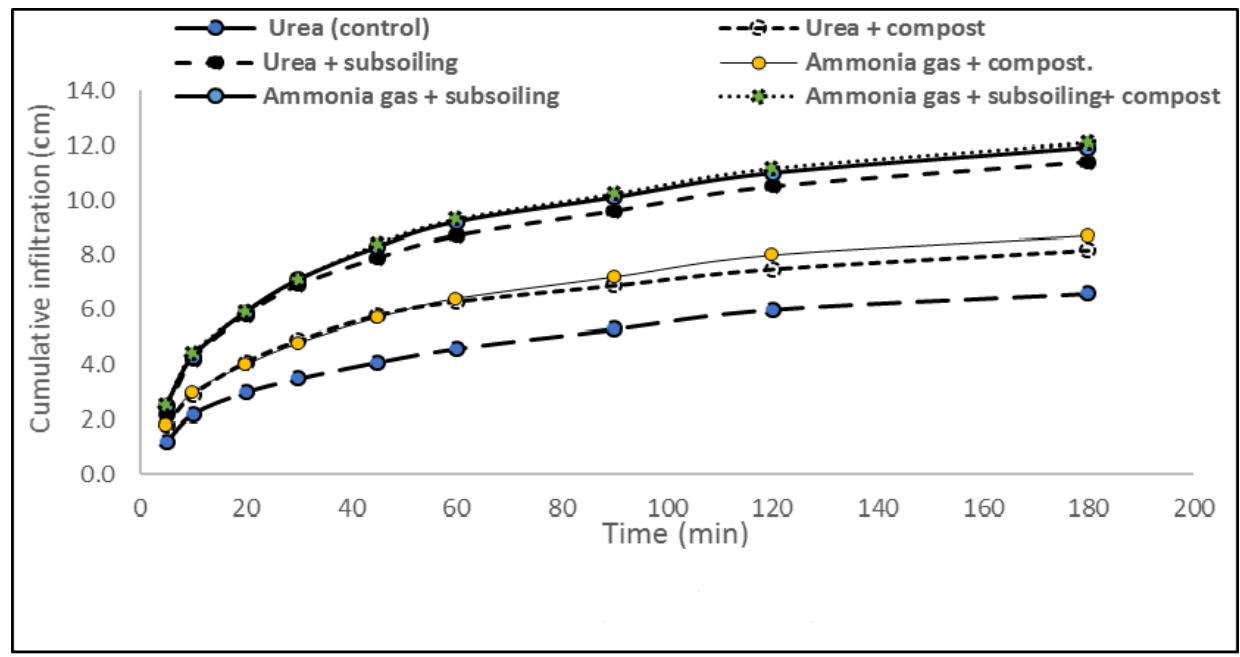

Fig. (4): Cumulative infiltration (cm) after the second season as affected by treatments application.

\section{Pore size distribution:}

Pore size distribution (quickly drainable pores (QDP), slowly drainable pores (SDP), water holding pores (WHP) and fine capillary pores(FCP)) of the studied soil are presented in (Table, 5 and Fig, 5). Results show that, the low value of QDP (8.17\%) and SDP $(9.96 \%)$ and high percent of FCP (28.09\%) are found with control treatment. These high values of FCP which are often filled with water and cause water logging, while plants grown in these soils suffer from drought. Treatments application were realized increases of QDP (varied from 9.76 to $13.38 \%$ ) and SDP (varied from 10.47 to $15.36 \%$ ) and decrease of FCP (varied from 24.56 to $17.86 \%$ ). The increases of QDP and SDP and decreases of FCP are more pronounced with subsoiling with and without compost treatments compared to compost without subsoiling. Results also indicate that, subsoiling with compost is superior to subsoiling without compost in enhancing of pore size distribution in soil. The average values of QDP were 11.00,11.74, 10.91, 12.00 and $13.03 \%$ for compost with urea, subsoiling with urea, compost with ammonia gas, subsoiling with ammonia gas and subsoiling with compost and ammonia, respectively. The corresponding values are 11.32, 14.97, 11.13, 15.09 and 15.11\%, respectively for SDP and 24.00, 19.71, 24.02, 19.04 and $17.99 \%$, respectively for FCP. Results showed that, subsoiling tend to enhancing of pore size distribution in soil. It could be attributed to the effects of subsoiling on breaking soil clods and bigger granular into smaller crumbs as well as breaking and cracking the compacted layers. In this concern, Abdel-Mawgoud (2004) found that subsoiling resulted in a noticeable increase in macro-pores with a consequent decrease in micro-pores compared with the control treatment. The applied compost was realized desirable effects in pore size distribution especially in the top soil layer. In this concern Cook et al., (1979) reported that, improvements of the soil after compost application included an increase in water infiltration rate, a decrease in bulk density, and an increase in pore volume. Results (Table, 5 and Fig, 5) showed that, subsoiling and/or compost tend to enhancing of WHP\% compared to control treatment. Nitrogen fertilizer sources (ammonia gas and urea) had not realized differences in pore size distribution in soil. 
Table (5): Pore size distribution (QDP, SDP, WHP, FCP \%) with soil depths after second season from treatments application.

\begin{tabular}{|c|c|c|c|c|c|}
\hline Treatments & $\begin{array}{l}\text { Soil depth } \\
\text { (cm) }\end{array}$ & QDP\% & SDP\% & WHP\% & FCP\% \\
\hline \multirow{3}{*}{ Urea (control) } & $0-15$ & 9.03 & 10.21 & 22.79 & 27.86 \\
\hline & $15-30$ & 7.59 & 9.78 & 22.13 & 28.54 \\
\hline & $30-60$ & 7.89 & 9.89 & 22.91 & 27.88 \\
\hline \multicolumn{2}{|c|}{ Average } & 8.17 & 9.96 & 22.61 & 28.09 \\
\hline \multirow{3}{*}{ Urea + compost } & $0-15$ & 11.93 & 11.37 & 23.28 & 23.56 \\
\hline & $15-30$ & 11.32 & 11.43 & 23.35 & 23.87 \\
\hline & $30-60$ & 9.76 & 11.16 & 23.55 & 24.56 \\
\hline \multicolumn{2}{|c|}{ Average } & 11.00 & 11.32 & 23.39 & 24.00 \\
\hline \multirow{3}{*}{ Urea + subsoiling } & $0-15$ & 12.01 & 15.01 & 23.82 & 19.03 \\
\hline & $15-30$ & 12.40 & 15.15 & 23.10 & 19.77 \\
\hline & $30-60$ & 10.81 & 14.76 & 23.55 & 20.34 \\
\hline \multicolumn{2}{|c|}{ Average } & 11.74 & 14.97 & 23.49 & 19.71 \\
\hline \multirow{3}{*}{$\begin{array}{l}\text { Ammonia gas + } \\
\text { compost }\end{array}$} & $0-15$ & 11.99 & 10.47 & 23.40 & 24.25 \\
\hline & $15-30$ & 10.19 & 11.73 & 24.00 & 23.95 \\
\hline & $30-60$ & 10.56 & 11.19 & 24.70 & 23.87 \\
\hline \multicolumn{2}{|c|}{ Average } & 10.91 & 11.13 & 24.03 & 24.02 \\
\hline \multirow{3}{*}{$\begin{array}{l}\text { Ammonia gas + } \\
\text { subsoiling }\end{array}$} & $0-15$ & 12.11 & 15.28 & 23.97 & 18.87 \\
\hline & $15-30$ & 12.48 & 15.10 & 23.40 & 19.14 \\
\hline & $30-60$ & 11.40 & 14.88 & 24.44 & 19.12 \\
\hline \multicolumn{2}{|c|}{ Average } & 12.00 & 15.09 & 23.94 & 19.04 \\
\hline \multirow{3}{*}{$\begin{array}{l}\text { Ammonia gas + } \\
\text { subsoiling } \\
+ \text { compost }\end{array}$} & $0-15$ & 13.22 & 15.36 & 23.79 & 17.96 \\
\hline & $15-30$ & 13.38 & 15.20 & 23.46 & 18.15 \\
\hline & $30-60$ & 12.49 & 14.76 & 24.75 & 17.86 \\
\hline \multicolumn{2}{|c|}{ Average } & 13.03 & 15.11 & 24.00 & 17.99 \\
\hline
\end{tabular}


Impact of subsoiling, organic manure and nitrogen sources on some

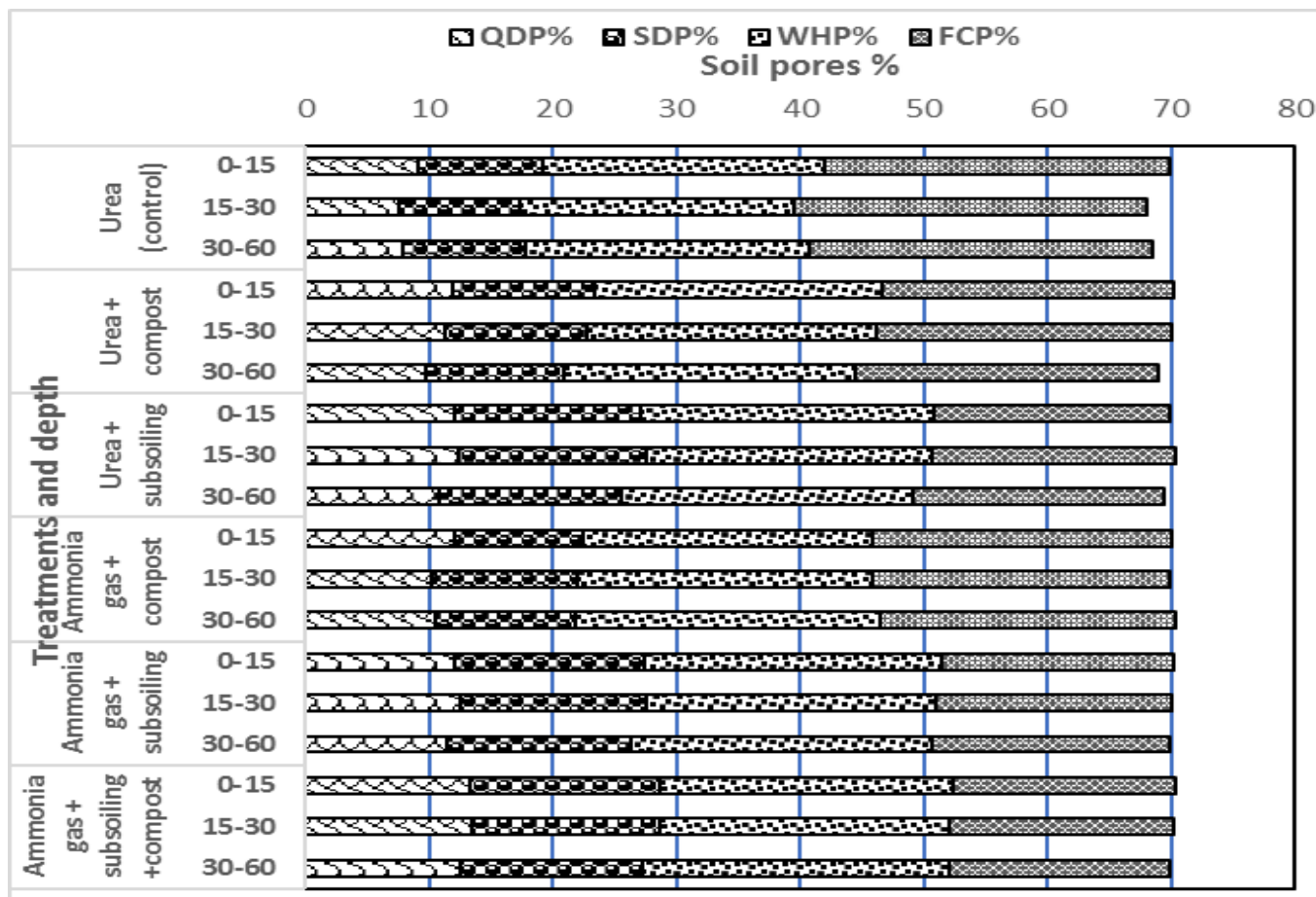

Fig. (5): Pore size distribution (QDP, SDP, WHP, FCP \%) with soil depths for different treatments.

\section{Yields:}

Data in Table (6) indicate that, subsoiling and/or compost as well as nitrogen sources caused significant increases of sugar beet yield compared to control. The yields are increased when improving soil properties as affected by treatments application. It can be concluded that heavy clay salt affected soils could have good productivity with the execution of subsoiling and compost. Sugar beet roots yield are higher with application of subsoiling and/or compost especially with ammonia gas injection than that control. The increases of sugar beet roots yield are 1.58, $5.09,2.68,6.36$ and 6.38 ton fed. ${ }^{-1}$ for compost +urea, subsoiling+ urea, compost+ ammonia gas, subsoiling+ ammonia gas and subsoiling+ compost +ammonia, respectively over than control in the first season. The corresponding values were $2.54,5.26,3.31,6.41$ and 6.72 tonfed.-1, respectively in the second season. The increases of sugar beet root yield are more pronounced with subsoiling with and without compost compared to compost without subsoiling. Such findings may be attributed to the effect of subsoiling and/or compost on improving soil properties which affects water-air relationships in the root zone and increase the root penetration. In this regard, Abdel-Mawgoud et al., (2006) mentioned that the subsurface tillage was superior in enhancing the sugar beet yield. It can be concluded that under such conditions the subsoiling and/or compost are the most effective treatments that ameliorate saline sodic clay soil. Similar results were obtained by Lickacz (1993), Aiad et al., (2012) and ElSanat et al., (2012). Data (Table 6) show that, there were no obvious differences between shoot yield with all treatments and, the values varied from 2.66 to 3.02 ton $\mathrm{fed}^{-1}$. Results (Table 6) show that, anhydrous ammonia injected before sowing with subsoiling and/or compost, gave higher root yield of sugar beet than mineral nitrogen 
source (urea) with subsoiling and/or compost. Abd El-Kader (2002) reported that when the anhydrous ammonia injected before sowing, gave higher yield and minerals uptake than other nitrogen sources.

Data in Table (7) show that, there were no obvious differences between sugar percentages with all treatments. Data showed that, the low values of juice quality of sugar beet (average of $78.78 \%$ ) were found with control treatment, and the high values (varied from 79.94 to $84.16 \%$ ) were found with treatments in both seasons. Data in Table (7) showed that, gross sugar yield were parallel to the sugar beet yield in both seasons. The increases of gross sugar yield are $0.25,0.87,0.49,1.15$ and 1.12 ton fed. $^{-1}$ for compost +urea, subsoiling + urea, compost+ ammonia gas, subsoiling+ ammonia gas and subsoiling+ compost + ammonia, respectively over than control in the first season. The corresponding values were $0.34,0.88,0.57,1.16$ and 1.18 tonfed. ${ }^{-1}$, respectively for the above mentioned treatments in the second season.

Data in Table (8) showed that, $\mathrm{N}$-uptake by sugar beet roots and shoots were parallel to the yield results in both seasons. Data showed that, the low values of $\mathrm{N}$-uptake by root of sugar beet (average of $36.69 \mathrm{kgfed}^{-1}$ ) were found with control treatment, and the high values (varied from 40.10 to 52.16 $\mathrm{kgfed}^{-1}$ ) were found with treatments application in both seasons. The increases of $\mathrm{N}$-uptake by sugar beet roots and shoots are more pronounced with anhydrous ammonia injected with subsoiling and/or compost compared to mineral nitrogen source (urea) and control. Results also indicate that, subsoiling is superior to compost in enhancing of $\mathrm{N}$-uptake by sugar beet roots. Abd El-Kader (2002) reported that when the anhydrous ammonia injected before sowing, gave higher yield and minerals uptake than other nitrogen sources.

Table (6): Sugar beet yields with different studied treatments.

\begin{tabular}{|l|c|c|c|c|}
\hline \multirow{2}{*}{ Treatments } & \multicolumn{4}{c|}{ Sugar beet yields (Ton/fed.) } \\
\cline { 2 - 5 } & \multicolumn{2}{|c|}{ First Season } & \multicolumn{2}{c|}{ Second Season } \\
\hline & Roots & Shoots & Roots & Shoots \\
\hline Urea (control) & $16.32 \mathrm{c}$ & $2.77 \mathrm{~b}$ & $16.36 \mathrm{~d}$ & $2.73 \mathrm{~b}$ \\
\hline Urea + compost & $17.90 \mathrm{~b}$ & $3.02 \mathrm{a}$ & $18.90 \mathrm{c}$ & $3.01 \mathrm{a}$ \\
\hline Urea + subsoiling & $21.42 \mathrm{a}$ & $2.66 \mathrm{~b}$ & $21.62 \mathrm{~b}$ & $2.79 \mathrm{~b}$ \\
\hline Ammonia gas + compost. & $19.23 \mathrm{~b}$ & $2.88 \mathrm{ab}$ & $19.67 \mathrm{c}$ & $2.92 \mathrm{ab}$ \\
\hline Ammonia gas + subsoiling & $22.68 \mathrm{a}$ & $2.78 \mathrm{ab}$ & $22.77 \mathrm{a}$ & $2.84 \mathrm{ab}$ \\
\hline $\begin{array}{l}\text { Ammonia gas + } \\
\text { subsoiling+ compost }\end{array}$ & $22.70 \mathrm{a}$ & $2.88 \mathrm{ab}$ & $23.08 \mathrm{a}$ & $2.85 \mathrm{ab}$ \\
\hline LSD $0.05 \%$ & 1.67 & 0.23 & 1.02 & 0.21 \\
\hline
\end{tabular}


Table (7): Sugar $\%$, sugar quality $\%$ and gross sugar yield (Ton fed ${ }^{-1}$ ) with different studied treatments.

\begin{tabular}{|c|c|c|c|c|c|c|}
\hline \multirow{3}{*}{ Treatments } & \multicolumn{6}{|c|}{ Sugar yields } \\
\hline & \multicolumn{2}{|c|}{ Sugar \% } & \multicolumn{2}{|c|}{ Quality \% } & \multicolumn{2}{|c|}{$\begin{array}{l}\text { Gross sugar } \\
\left(\text { Ton fed }^{-1}\right)\end{array}$} \\
\hline & $\begin{array}{c}\text { First } \\
\text { Season }\end{array}$ & $\begin{array}{l}\text { Second } \\
\text { Season }\end{array}$ & $\begin{array}{c}\text { First } \\
\text { Season }\end{array}$ & $\begin{array}{l}\text { Second } \\
\text { Season }\end{array}$ & $\begin{array}{c}\text { First } \\
\text { Season }\end{array}$ & $\begin{array}{l}\text { Second } \\
\text { Season }\end{array}$ \\
\hline Urea (control) & 17.74 b & 17.86 b & $78.53 \mathrm{f}$ & $79.05 \mathrm{e}$ & 2.27 & 2.31 \\
\hline Urea + compost & $17.58 \mathrm{~b}$ & $17.58 \mathrm{~b}$ & $79.94 \mathrm{e}$ & $80.23 d$ & 2.52 & 2.65 \\
\hline Urea + subsoiling & $17.88 a b$ & $17.83 \mathrm{~b}$ & $82.04 \mathrm{c}$ & $82.68 \mathrm{~b}$ & 3.14 & 3.19 \\
\hline $\begin{array}{l}\text { Ammonia gas + } \\
\text { compost. }\end{array}$ & $17.96 \mathrm{ab}$ & $18.01 \mathrm{a}$ & $80.94 \mathrm{~d}$ & $81.18 \mathrm{c}$ & 2.76 & 2.88 \\
\hline $\begin{array}{l}\text { Ammonia gas + } \\
\text { subsoiling }\end{array}$ & $18.01 \mathrm{a}$ & $18.11 \mathrm{a}$ & $83.79 \mathrm{a}$ & $84.13 \mathrm{a}$ & 3.42 & 3.47 \\
\hline $\begin{array}{l}\text { Ammonia gas + } \\
\text { subsoiling +compost }\end{array}$ & $17.95 \mathrm{ab}$ & $17.97 \mathrm{ab}$ & $83.19 \mathrm{~b}$ & $84.22 \mathrm{a}$ & 3.39 & 3.49 \\
\hline LSD $\quad 0.05 \%$ & 0.22 & 0.21 & 0.49 & 0.78 & - & - \\
\hline
\end{tabular}

Table (8): $\mathrm{N}$-uptake of Sugar beet $\left(\mathrm{kg} \mathrm{fed}^{-1}\right)$, with different studied treatments.

\begin{tabular}{|c|c|c|c|c|}
\hline \multirow{3}{*}{ Treatments } & \multicolumn{4}{|c|}{$\mathrm{N}$-uptake of Sugar beet $\left(\mathrm{kg} \mathrm{fed}^{-1}\right)$} \\
\hline & \multicolumn{2}{|c|}{ First Season } & \multicolumn{2}{|c|}{ Second Season } \\
\hline & Roots & Shoots & Roots & Shoots \\
\hline Urea (control) & $36.71 \mathrm{c}$ & 17.76 b & $36.65 d$ & $17.69 \mathrm{~b}$ \\
\hline Urea + compost & $40.09 \mathrm{~b}$ & $18.73 a b$ & $40.63 \mathrm{c}$ & $19.01 \mathrm{a}$ \\
\hline Urea + subsoiling & $41.76 \mathrm{~b}$ & $16.96 \mathrm{~b}$ & $41.50 \mathrm{c}$ & $18.03 a b$ \\
\hline Ammonia gas + compost. & $42.94 \mathrm{~b}$ & $18.81 \mathrm{ab}$ & $43.75 b$ & $19.04 \mathrm{a}$ \\
\hline Ammonia gas + subsoiling & $51.26 \mathrm{a}$ & $18.80 \mathrm{ab}$ & $51.24 \mathrm{a}$ & $19.20 \mathrm{a}$ \\
\hline $\begin{array}{l}\text { Ammonia gas + subsoiling+ } \\
\text { compost }\end{array}$ & $51.53 \mathrm{a}$ & $19.58 \mathrm{a}$ & $52.15 \mathrm{a}$ & $19.26 \mathrm{a}$ \\
\hline LSD $\quad 0.05 \%$ & 3.30 & 0.98 & 2.17 & 1.01 \\
\hline
\end{tabular}

\section{Conclusion}

* subsoiling is proper way to enhancing the characteristics of clay soils.

* subsoiling tend to improve soil physiochemical characteristics and increase crop production.

\section{REFERENCES}

Abd El-Kader, G. Mona (2002). Response of growth and yield of wheat "cv. SED 57 "to Fe and $\mathrm{Zn}$ application under ammonia injection $\mathrm{Ph}$. D Thesis, Fac. Agric. Moshtohor, Zagazig Univ., Egypt.

Abdel-Mawgoud, A.S.A (2004). Sobsoiling to conserve rootzone stratum of heavy clay soil. Minufiya J. Agric. Res. Vol. 29 No. 6: 1456-1478.

Abdel-Mawgoud, A.S.A., A.A.S. Gendy and S.A. Ramadan (2006). Improving root zone environment and production of a 
salty clay soil using subsoiling and gypsum application. Assiut J. of Agri. Sci., 37, 2: 147-164.

Aiad, M.A.F., M.A. Abd El-Aziz, B.A.A. Zamil and A.S. Antar (2012). Combating of soil deterioration at north delta, Egypt. $J$. Agric. Res. Kafr El-Sheikh Univ., 38 (2), 322-341.

Amer, M. H. (1999). Effect of tillage operations on some soil physical properties and water relations of corn. Egypt, J. Appl. Sci., 14 (6):354-365.

Antar, A. S. and M.Y.M. Awad (2014). Impact of nitrogen sources on nitrate losses into tile drain in clay soil under sugar beet crop. Middle East Journal of Agricultural Research. Vol. 3 (4): 936942.

Antar, A. S., G. M. A. El-Sanat and H. A. Khafagi (2014). Improving heavy clay salt affected soil and its production using some amendments application in north delta. J. of Soil Sciences and Agricultural Engineering. Mansoura Univ. Vol. 5 (12): 1717-1730.

Atia, R.H., R.E. Knany, A.S.M. El-Saady and M.I. Zidan (2007). Sugar beet response to nitrogen forms and rates under different tillage practices .expressed by polynomial quadratic equation . Egypt. J Agric. Res., 85 (4): 1127-1139.

Bouajila, K. and M. Sanaa (2011). Effect of organic amendments on soil physic, chemical and biological properties. J. Mater Environ. Sci., 2: 485 - 490.

Campbell, D.J. (1994). Determination and use of bulk density in relation to soil compaction. In Soane and Ouwerk (Eds). Soil compaction in crop production. Elsever, London and Amsterdam.

Cook, R.N., J.C. Patterson and J.R. Short (1979). Compost saves money in parkland restoration, Compost Sci. Util., 20 (2), 43.

Cottenie, A., P.M. Verloo, L. Kiekens, G Velghe and R. Camerlynck (1982). Chemical Analysis of Plants and Soils. Lab. Anal. and Agrochem. State Univ.,
Gent. Belgium, Chapter 2 and 3, pp 1454.

De Leenher, L. and M. De Boodt (1965). Soil physics. Intre. Training Center for Post Graduate Soil Scientists, Gent., pp. 126135.

Doran, J.W. and T.B. Parking (1994). Defining and assessing soil quality, in Defining soil quality for a Sustainable Environment, Doran, J.W., Coleman, D. C., Bezdicek, D. F., and Steward, B.A. Eds., SSSA Special Publication Number 35, SSSA, Madison, WI,3.

El- Sanat, G.M.A. (2012). Effect of some soil management practices and nitrogen fertilizer levels on some soil properties and its productivity at North Delta . J.Soil Sci. and Agric. Eng. , Mansoura Univ., vol. 3 ( 12 ) : 1137 - 1151 , 2012.

El-Hamdi, Kh. H., S.A. Hammad, M.A. AbouElsoud and G.M.A. El-Sanat (2007). Effect of some amendments application on some soil physical and chemical properties . J. Agric., Sci., Mansoura Univ. vol. 32 No. ( 9 ) : 7967 - 7978.

Garcia, G. (1978). Soil water Engineering Laboratory Manual. Colorado State Univ. Dept. of Agric. and Chemical Engineering. Fortcollins, Colorado.

Jodi DeJong, H. (2004). Can subsoiling increase crop yields in Minnesota? Agric. World Wide Correspondent. Meredith Coporation.

Lickacz, J. (1993). Management of solonetzic soils. Agdex 518-8. Revised, Edmonton, Alberta, Canada.

Mostafa, Shafika N. and S.D. Darwish (2001). Biochemical studies on the efficiency use of some nitrogen fertilizers sugar beet production. J. Agric. Sci.Mansoura Univ., 26 (4): 2421- 2429.

Moukhtar, M.M., E.M. El-Hadidy, M.Y.S. ElArquan and M.A.B. El-Shewikh (2002). Soil Amelioration Technique of Cover Drainage Combined Subsoiling for Saline-Sodic Clay in North Egypt. XVth World Congress of the International Commission of Agricultural Engineering 
(CIGR) on July 28-31 - 2002, Chicago, USA.

Moukhtar, M.M., M.Y.S. El-Arquan, E.M. ElHadidy and M.A.B. El-Shewikh (2003). Amelioration of salt affected soils in north Dakhlia Governorate through application of tile drainage and subsoiling. J. Agric. Sci. Mansoura Univ., Special Issue, Sci. Symp. On Problems of soils and waters in Dakhlia and Damietta Governorate. March 18.

Page, A.L., R.H. Miller and D.R. Keeney (1982). Methods of Soil Analysis. Part П: Chemical and microbiological properties, $2^{\text {nd }}$ ed. Soil Sci. Soc. Am. Inc., Madison, USA.

Richards, L.A. (1954). Diagnosis and Improvement of Saline and Alkali Soils U.S.D.A. Hand Book No. 60.

Said, H.M. (2002). Effect of deep ploughing on some physical properties and corn yield in calcareous sandy clay loam soil. Egyp. J. Soil Sci. 42: 57-70.

Said, H.M. (2003). Effect of tillage implements on the state of compaction in different soils. Egyp. J. Soil Sci. 43: 91107.

Snedecor, G.W. and W.G. Cochran (1980). "Statistical Methods" $7^{\text {th }}$ ed., 225-330. Iowa state Univ., Press., Ames., lowa, USA.

Yadav, K. K. and B.R. Chippa (2007). Effect of FYM, gypsum and iron pyrites on fertility status of soil and yield of wheat irrigated with high RSC water. J. of Indian Soc. of Soil Sci., 55: 20-302.

Zalat, S.S., Kh. A. AboShady, M.F.M. Ibrahim and Samia M.M. Helal (2011). Effect of injection ammonia gas under different levels and depths on yield and quality of sugar beet. J.Agric. Res. Kafr El-Sheikh Univ., 37 (1) 43-56. 
تأثير الحرث تحت التربة والسماد العضوي ومصادر النتروجين على بعض خصائص الأرض وإنتاجية بنجر السكر ومداد

\author{
جمال محمد عبدالسلام الصناط \\ معهد بحوث الأراضي والمياه والبيئة - مركز البحوث الزراعية- الجيزة - مصر
}

الملخص العربي

الإهتمام بالصرف ورفع كفاءة الأسمدة تلعب دوراً هاماً في إدارة الأراضي وزيادة الإنتاجية. وتهدف الدراسة الى تقييم

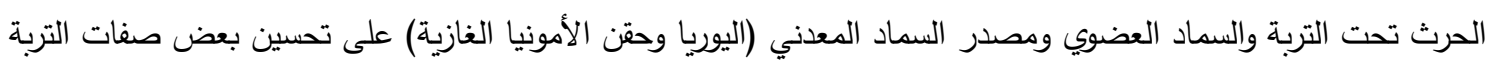

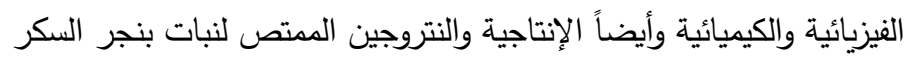
وتوضح النتائج أن:أدت معاملات الحرث تحت التربة الى تقليل الملوحة والصودية خصوصا بعد عامين من التنفيذ. حيث كان النقص في

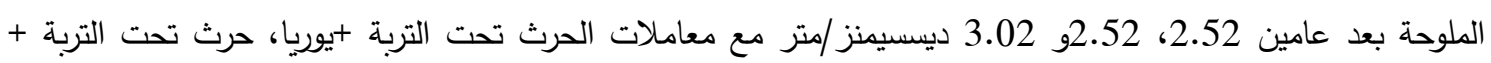

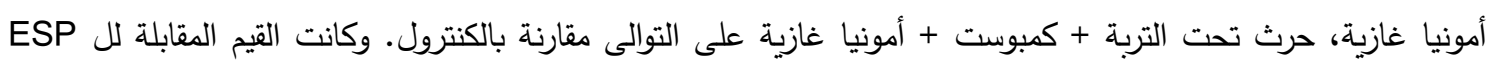

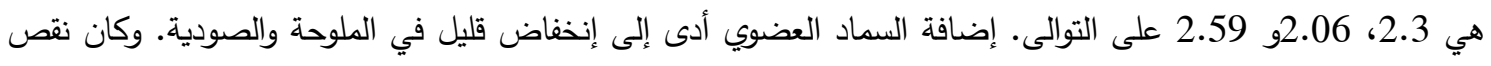

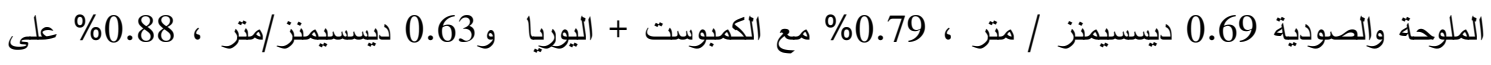

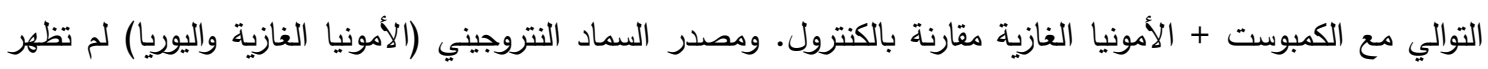
تأثير على ملوحة وصودية التربة.

الحرث تحت التربة مع وبدون السماد العضوي كان لة أثر فعال في تحسين الكثافة الظاهرية والمسامية الكلية. حيث قلت

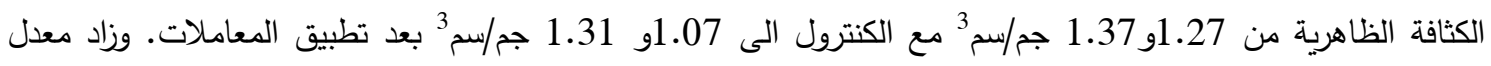

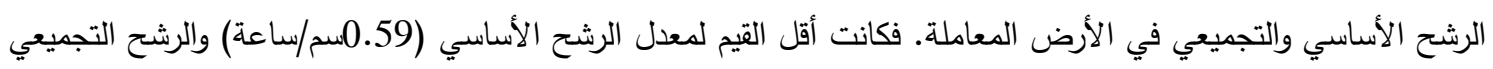

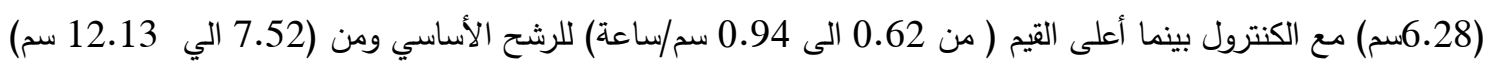
للرشح التجميعي. والحرث تحت التربة كان لة أثر فعال في تحسين مسام الصرف السريعة والمتوسطة والمسام الثعرية الدقيقة

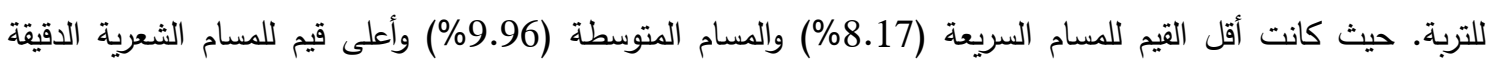

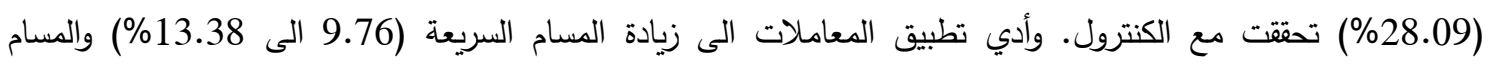

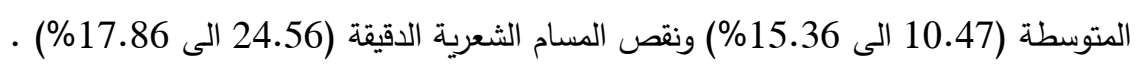

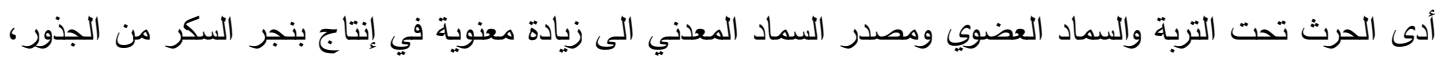

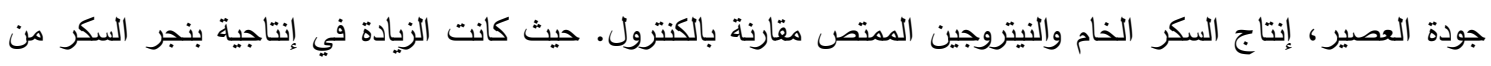

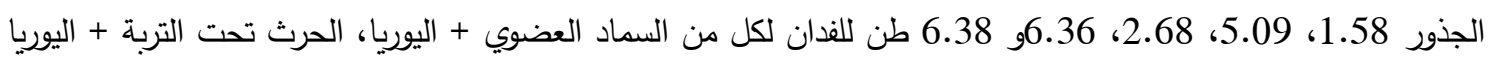

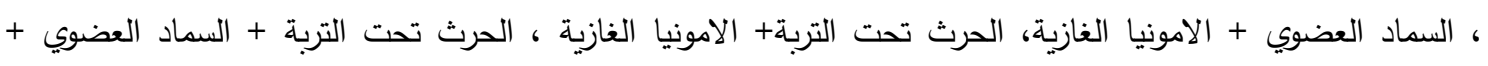

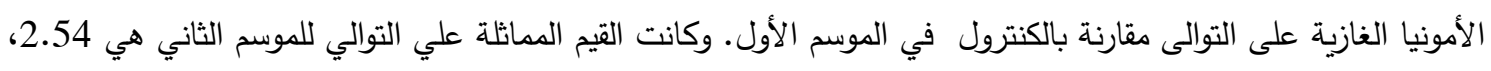

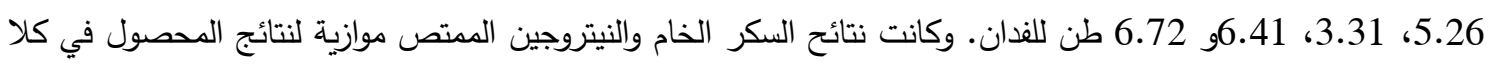

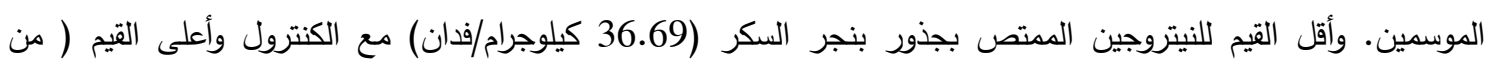

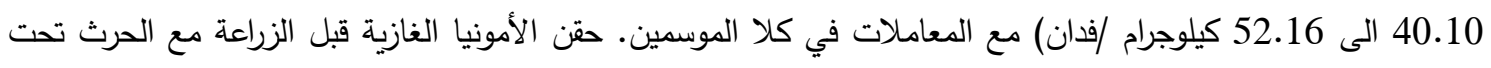
التربة أو السماد العضوي حقق أعلى قيمة من المحصول والنيتروجين الممتص مقارنة بالأسمدة المعدنية. 
Impact of subsoiling, organic manure and nitrogen sources on some ........... 